\title{
Endoscopic dacryocystorhinostomy. Results in 172 patients
}

\section{Dacriocistorrinostomía endoscópica. Resultados en 172 pacientes}

\author{
Eva Pablos-Buitrón ${ }^{1 *}$, Alejandro Martínez-Morán², Javier Lage-Fernández ${ }^{3}$, Patricia Cerdeira-Pena ${ }^{4}$, and \\ Vivian Pérez-Varela ${ }^{4}$ \\ ${ }^{1}$ Otolaryngology department, Hospital Universitario de Ferrol, Ferrol; ${ }^{2}$ Otolaryngology department, Hospital Universitario de A Coruña, A Coruña; ${ }^{3}$ Otolaryngology \\ department, Hospital La Rosaleda, Santiago de Compostela; ${ }^{4}$ Ophthalmology department, Hospital Universitario de A Coruña, A Coruña. Spain
}

\begin{abstract}
Introduction: Dacryocystorhinostomy is the technique of choice for the treatment of lower lacrimal duct obstruction and recurrent dacryocystitis. Although open surgery has the highest success rates, nowadays endoscopic techniques offer advantages in terms of duration of surgery, simplicity of the technique, reproducibility, absence of scarring, and reduction of discomfort for the patient, with a high success rate. Currently, endoscopic dacryocystorhinostomy is the chosen technique in the Hospital Universitario de A Coruña. Objective: The data of the surgeries performed for 3 years have been collected with the objective of analyzing the results comparing them with those described in the literature. Method: We analyzed the results of 172 patients with a total of 220 endoscopic dacryocystorhinostomies performed between January 2014 and March 2017. Results: According to the patency test, the success rate was $83.5 \%$, and only $12.7 \%$ required reoperation. Conclusions: Endoscopic dacryocystorhinostomy is currently the preferred technique for ophthalmologists and otorhinolaryngologists for the treatment of chronic lacrimal obstruction. Its success rates are high, and it offers multiple advantages over the open technique.
\end{abstract}

Key words: Lacrimal duct obstruction. Endoscopic. Dacryocystorhinostomy. Epiphora. Dacryocystitis.

\section{Resumen}

Introducción: La dacriocistorrinostomía es la técnica de elección para el tratamiento de la obstrucción de la vía lagrimal baja y de la dacriocistitis de repetición. A pesar de que la cirugía abierta tiene los mayores porcentajes de éxito, hoy en día las técnicas endoscópicas ofrecen ventajas en cuanto a duración de la cirugía, sencillez de la técnica, reproducibilidad, ausencia de cicatriz y disminución de las molestias para el paciente, con una alta tasa de éxito. Actualmente la técnica elegida en el Hospital Universitario de A Coruña es la dacriocistorrinostomía endoscópica. Objetivo: Se han recogido los datos de las cirugías realizadas durante 3 años con el objetivo de analizar los resultados comparándolos con los descritos en la literatura. Método: Se recogieron los resultados de 172 pacientes con un total de 220 dacriocistorrinostomías endoscópicas entre enero de 2014 y marzo de 2017. Resultados: El éxito según el test de permeabilidad fue del 83.5\% y solo el 12,7\% necesitaron una reintervención. Conclusiones: La dacriocistorrinostomía endoscópica es actualmente la técnica preferida por oftalmólogos y otorrinolaringólogos para el tratamiento de la obstrucción crónica de la vía lagrimal. Sus tasas de éxito son altas y ofrece múltiples ventajas sobre la técnica abierta.

Palabras clave: Obstrucción del conducto lacrimal. Endoscópica. Dacriocistorrinostomía. Epífora. Dacriocistitis.

Correspondence:

*Eva Pablos Buitrón

San Sebastián 19, 7B

Date of reception: 22-09-2020

C.P. 15007, A Coruña, Spain

E-mail: evapablosorl@gmail.com

2604-1731/C 2021 Sociedad Mexicana de Oftalmología. Published by Permanyer. This is an open access article under the CC BY-NC-ND license (http://creativecommons.org/licenses/by-nc-nd/4.0/).
Available online: 19-03-2021 Rev Mex Oftalmol (Eng). 2021;95(4):137-141

www.rmo.com.mx
Date of acceptance: 16-03-2021 


\section{Introduction}

Dacryocystorhinostomy (DCR) is the surgery of choice for the treatment of epiphora due to nasolacrimal duct obstruction, as well as for recurrent dacryocystitis $^{1,2}$, restoring tear drainage towards the nasal cavities.

It has been described that, in most cases, lacrimal duct obstruction is due to an alteration in the drainage of the lacrimal sac, which is why such cases of epiphora, or sac infection can be resolved by $\mathrm{DCR}^{3}$.

In our hospital, the diagnosis is made by the ophthalmology department in the tear duct section using the lacrimal syringing technique, and for years the surgery has been performed jointly with the otorhinolaryngology department. This test consists of the canalization of one lacrimal punctum and the instillation of saline solution. In the case of sacal or postsacal obstruction, there is reflux through the other punctum. These are the patients in which this surgery is useful.

Although the external approach technique is the one with the highest success rates ${ }^{4-6}$, in many hospitals the endoscopic technique is preferred because it has clear advantages, like the speed of the procedure, faster patient recovery, reproducibility of the technique, and the absence of scar. DCR by external approach implies a longer surgical time, the need for an external incision and a greater possibility of bleeding 7,8 .

The objective of this study was to analyze the results of endoscopic DCR in our department, compare them with those described in the literature, and describe possible surgical complications.

\section{Methods}

Data from patients operated between January 2014 and March 2017 were collected retrospectively, for a total of 172 patients. The cases of bilateral surgery were counted as two independent procedures, for a total of 220 interventions, carried out jointly by the ophthalmology and otorhinolaryngology departments. We included data on the existence of previous nasal surgery, vasculitis, blepharitis or dacryocystitis, and also on complications, such as epistaxis. The anatomical success was determined by verifying patency and by the absence of dacryocystitis, and the functional or subjective success was determined by the improvement of patient-reported symptoms.

Data were analyzed using the IBM SPSS Statistics 24.0 program, with the collaboration of the hospital's statistics department. We performed a descriptive retrospective analysis of the variables collected in the study. Quantitative variables are expressed as mean \pm standard deviation, and qualitative variables as frequency and percentage.

The association between qualitative variables was estimated using the chi-square test or Fisher's test. The impact of the different variables on the need for a second intervention was analyzed using logistic regression models, adjusting for those that were significant in the univariate analysis or for those clinically relevant.

\section{Surgical technique}

In most cases, patients were operated under local anesthesia and sedation in the regular and scheduled operating room.

Topical drops of double anesthetic were administered on the conjunctiva and the patency test was performed again with the same anesthetic for a final check.

The nostril was explored prior to surgery to rule out anatomical variations that complicated access to the lateral wall of the fossa, such as nasal septum deviation or concha bullosa. We used in the surgeries $4 \mathrm{~mm}$ and $30^{\circ}$ endoscopes. Patties soaked in double anesthetic and 1:1000 epinephrine were introduced into the middle meatus and over the lower and middle turbinate.

Subsequently, the mucosa that covers the frontal process of the maxilla and the lacrimal bone was infiltrated with mepivacaine and epinephrine. We waited between 5 and 10 minutes to achieve the maximum effect of anesthesia and vasoconstriction.

The mucosa was incised with a sickle-shaped scalpel to reveal the frontal process of the maxillary bone, and a small mucosal flap was made to facilitate exposure.

With two 2-mm Smith-Kerrison forceps and $90^{\circ}$ and $45^{\circ}$ angulations, several fragments of the frontal process of the maxilla and the lacrimal bone were extract$\mathrm{ed}$, to visualize the medial aspect of the sac.

The probing of the lacrimal duct was then carried out using a Bowman catheter, favoring the protrusion of its wall, and incising the sac with the sickle-shaped scalpel. The medial wall of the sac was resected with the punch technique.

The probing of the lacrimal duct was carried out with the bicanalicular silicone probe. To prevent healing and closure of the osteotomy, $0.4 \%$ topical mitomycin was used in all patients for 5 minutes, with subsequent washing of the area with saline solution.

Finally, a tamponade was performed until the patient was discharged home, with a series of instructions that 
included flushing the nostril with saline solution starting the day after surgery, antibiotic and corticosteroid eye drops, and analgesia.

During reoperations, the previous scar was resected, intubation was performed, and mitomycin $\mathrm{C}$ was applied again.

All patients were reviewed 15 days after the procedure in the otolaryngology service. In this consultation, an attempt was made to eliminate potential endonasal scabs from the operated area. The next appointment, after verifying the favorable healing of the operated area, was 2 months after surgery to remove the probe. Successive examinations were carried out in the ophthalmology service, where the patency of the lacrimal drainage system was evaluated using the probing and irrigation technique, the healing of infections in case of dacryocystitis and the resolution of the patients' symptoms.

\section{Results}

The data of 172 patients were analyzed, adding a total of 220 interventions. Seventy-five percent were women and $25 \%$ men, with a mean age of 70 years (range: 31-94 years). Regarding personal history, 92\% were non-smokers, $39 \%$ were taking antiplatelet drugs, and $50 \%$ were taking antihypertensive drugs.

A total of $74(33.6 \%)$ had previous episodes of dacryocystitis and $36(16.4 \%)$ of blepharitis. Only 20 cases were reoperations (9.09\%). Regarding surgery, $70.9 \%$ was unilateral and $71.8 \%$ was performed under local anesthesia and sedation. The mean follow-up period was of 14 months (range: 12-35 months).

Anatomical success, according to the patency test at the end of follow-up, was $83.6 \%$. Subjective success, according to patient satisfaction regarding the total cessation of symptoms, was $77 \%$. From all cases, $12.7 \%$ were bilateral.

Using univariate logistic regression models, it was observed that dacryocystitis and blepharitis are the only variables with independent effects to predict the need for a second intervention. Patients with previous dacryocystitis have a lower probability of reoperation (odds ratio [OR]: 0.19; confidence interval $[\mathrm{Cl}]$ : 0.100.90). In contrast, patients with blepharitis have six times the risk of needing reoperation (OR: 6.03; Cl: $2.55-14.27)$. Sex $(p=0.089)$ and antiplatelet treatment $(p=0.069)$ are at the limit of significance. The male sex has a lower risk of reoperation, and antiplatelet treatment (OR: 0.15 ) decreases the probability of needing a new intervention. Age does not introduce a statistically significant impact, although the older the age (OR: $0.99 ; \mathrm{Cl}: 0.96-1.02)$ there is a downward trend in the performance of a second intervention.

Adjusting for age, sex, dacryocystitis and blepharitis, it is observed that the only variable with independent effect to predict the need for a new intervention is blepharitis. Patients with blepharitis (OR: 5.10; Cl: 2.1012.42) have five times the risk of requiring a reoperation than patients without blepharitis. Only $4(1.8 \%)$ of the cases with previous dacryocystitis had another episode of infection after the intervention.

Regarding complications, 4 (1.8\%) patients were admitted due to epistaxis that required anterior tamponade, and all had resolution of epiphora after surgery.

\section{Discussion}

Although DCR by external approach is the technique with the highest success rates ${ }^{4-6,9}$, from $80-95 \%, 7,-13$, it has clear disadvantages compared to the endoscopic technique, such as the higher percentage of need for general anesthesia, the longer surgical time $e^{5,14}$, the involvement of the valvular mechanism of the lacrimal duct and the external scar ${ }^{15}$. With the endoscopic technique, surgery can be performed in most cases with sedation and local anesthesia, reducing discomfort, and without the need for admission, so that elderly patients can opt for the intervention, which also presents minimal complications; the most frequent in our group was epistaxis, in $1.8 \%$ of the cases, which resolved with anterior nasal packing.

We believe that joint action is necessary between the otolaryngology and ophthalmology departments since the diagnosis is established by the ophthalmology department and the endonasal surgical approach is carried out by the otolaryngology department.

Our success rate is comparable to those reported in the literature $4,16,17$, with patency at the end of follow-up of $83.5 \%$ and a revision rate of surgery of $12.7 \%$, which does not usually mean a great discomfort for the patient, even if he or she has to undergo additional surgery.

The statistically significant results that we have found are dacryocystitis as a protective factor and blepharitis as a risk factor, in terms of the need for a second intervention.

Regarding the success of the surgery with the different techniques, there is great variability between published articles. Patients with recurrent infections are usually satisfied if chronic dacryocystitis resolves, even though slight residual epiphora remains. For this 
reason, we understand that the success rate should be measured with the patency test and the subjective assessment of the result of the surgery according to the patient. In any case, we consider that we are facing a failure when we propose to the patient the possibility of a new surgery because the washout test is negative, and the patient is dissatisfied. There are patients with good permeability of the lacrimal duct verified by lacrimal syringing who are dissatisfied; in some cases, there may also be concomitant eyelid pathology that will not resolve with a new DCR.

Wormald ${ }^{16}$ studied the influence of the size of the osteotomy on the result of the surgery and concluded that with the exposure of the lacrimal sac as a whole, his results were comparable to those of the open technique. Currently, we understand that the osteotomy must allow the lacrimal duct to drain as horizontally as possible, so we must try to open the lacrimal sac in its entirety, but especially in the superior region.

Some authors report their success rates improve if instead of removing the mucosal flap, they introduce it in the residual $\operatorname{sac}^{15}$ to promote healing. We no longer perform this technique because, as it has been reported in the literature ${ }^{18}$, the results are comparable, and the size of the flap increases surgical time.

Regarding the application of mitomycin $\mathrm{C}$, its real usefulness is not clear either. It seems to improve the intranasal wound healing process ${ }^{19}$, but there is disagreement about its influence on the success rate in endoscopic techniques ${ }^{19,20}$, although it does provide significant improvements in external DCRs and in endoscopic DCR examinations ${ }^{21}$. We have not observed any complications from mitomycin use.

When we started with the endoscopic approach to DCR, the possibility of performing the osteotomy with a laser was initially proposed to us, due to the advantages observed by other authors ${ }^{17,22,23}$. For a few months we used this technology in our department, but finally the osteotomy had to be expanded with a bur or by a laminotomy, so we ended up abandoning it.

Pearlman et al. ${ }^{17}$ analyzed the results of the endoscopic technique using the YAG (yttrium aluminum garnet) laser and reported the advantage of fewer complications, with no cases of orbital fat exposure ${ }^{17}$.

Mann and Wormald ${ }^{24}$ studied the variation in the size of the ostium over time and concluded that changes in size occur during the first 4 weeks after surgery; therefore, we believe the follow-up time for our patients is adequate, with an average of 12 months.

\section{Conclusions}

We consider that endoscopic surgery for the treatment of nasolacrimal duct obstruction should be the main technique in our hospitals. It is a simple, safe, and fast approach, with a high success rate, which has allowed us to expand its indication in elderly patients.

As surgeons, otorhinolaryngologists, and ophthalmologists must collaborate to offer this type of surgery to patients. Today, the success rates are close to those of conventional open surgery, with significant benefits over it.

\section{Funding}

No funding was received for this research.

\section{Conflicts of interest}

The authors declare no conflicts of interest.

\section{Ethical disclosures}

Protection of human and animal subjects. The authors declare that no experiments were performed on humans or animals for this study.

Confidentiality of data. The authors declare that they have followed the protocols of their work center on the publication of patient data.

Right to privacy and informed consent. The authors have obtained the written informed consent of the patients or subjects mentioned in the article. The corresponding author is in possession of this document.

\section{References}

1. Das SK, Sarkar P, Dan A, Boral K, Basak B, Banerjee SN. Endoscopic dacryocystorhinostomy: a study at IPGMER, Kolkata. Indian J Otolaryngol Head Neck Surg. 2013;65(Suppl 2):366-70.

2. Marcet MM, Kuk AK, Phelps PO. Evidence-based review of surgical practices in endoscopic endonasal dacryocystorhinostomy for primary acquired nasolacrimal duct obstruction and other new indications. Curr Opin Ophthalmol. 2014;25:443-8.

3. Avdagic E, Phelps PO. Nasolacrimal duct obstruction as an important cause of epiphora. Dis Mon. 2020;66:101043.

4. Hartikainen J, Antila J, Varpula M, Puukka P, Seppä H, Grénman R. Prospective randomized comparison of endonasal endoscopic dacryocystorhinostomy and external dacryocystorhinostomy. Laryngoscope. 1998;108:1861-6.

5. Cokkeser Y, Evereklioglu C, Er H. Comparative external versus endoscopic dacryocystorhinostomy: results in 115 patients (130 eyes). Otolaryngol Head Neck Surg. 2000;123:488-91.

6. Tarbet KJ, Custer PL. External dacryocystorhinostomy. Ophthalmology. 1995; 102:1065-70.

7. Huang J, Malek J, Chin D, Snidvongs K, Wilcsek G, Tumuluri K, et al. Systematic review and meta-analysis on outcomes for endoscopic versus external dacryocystorhinostomy. Orbit. 2014;33:81-90.

8. Jawaheer L, MacEwen CJ, Anijeet D. Endonasal versus external dacryocystorhinostomy for nasolacrimal duct obstruction. Cochrane Database Syst Rev. 2017;(2):Cd007097. 
9. Tarbet KJ, Custer PL. External dacryocystorhinostomy. Surgical success, patient satisfaction, and economic cost. Ophthalmology. 1995;102:1065-70.

10. Dolman PJ. Comparison of external dacryocystorhinostomy with nonlaser endonasal dacryocystorhinostomy. Ophthalmology. 2003;110:78-84.

11. Mekonnen W, Adamu Y. Outcome of external dacryocystorhinostomy in Ethiopian patients. Ethiop Med J. 2009;47:221-6.

12. Fayers $T$, Laverde $T$, Tay $E$, Olver JM. Lacrimal surgery success after external dacryocystorhinostomy: functional and anatomical results using strict outcome criteria. Ophthalmic Plast Reconstr Surg. 2009;25:472-5.

13. Warren JF, Seiff SR, Kavanagh MC. Long-term results of external dacryocystorhinostomy. Ophthalmic Surg Lasers Imaging. 2005;36:446-50.

14. Lee DW, Chai CH, Loon SC. Primary external dacryocystorhinostomy versus primary endonasal dacryocystorhinostomy: a review. Clin Exp Ophthalmol. 2010;38:418-26.

15. Massegur Solench H, Trias Mis E, Ademà Alcover JM. Dacriocistorrinostomía endoscópica: técnica modificada. Acta Otorrinolaringol Esp. 2002;53:463-8.

16. Wormald PJ. Powered endoscopic dacryocystorhinostomy. Laryngoscope. 2002;112:69-72.
17. Pearlman SJ, Michalos $P$, Leib ML, Moazed KT. Translacrimal transnasal laser-assisted dacryocystorhinostomy. 1997;107:1362-5.

18. Kingdom TT, Barham HP, Durairaj VD. Long-term outcomes after endoscopic dacryocystorhinostomy without mucosal flap preservation. Laryngoscope. 2020;130:12-7.

19. Ragab SM, Elsherif HS, Shehata EM, Younes A, Gamea AM. Mitomycin C-enhanced revision endoscopic dacryocystorhinostomy: a prospective randomized controlled trial. Otolaryngol Head Neck Surg. 2012;147:937-42.

20. Majhi S, Sharma A. Evaluation of role of mitomycin $C$ in the cases of nasolacrimal duct blockage undergoing endoscopic dacryocystorhinostomy. Indian J Otolaryngol Head Neck Surg. 2019;71(Suppl 3):1981-5.

21. Xue K, Mellington FE, Norris JH. Meta-analysis of the adjunctive use of mitomycin $\mathrm{C}$ in primary and revision, external and endonasal dacryocystorhinostomy. Orbit. 2014;33:239-44.

22. Metson R, Woog JJ, Puliafito CA. Endoscopic laser dacryocystorhinostomy. Laryngoscope. 1994;104:269-74.

23. Reifler DM. Results of endoscopie KTP laser-assisted dacryocystorhinostomy. Ophthalmic Plast Reconstr Surg. 1993;9:231-6.

24. Mann BS, Wormald PJ. Endoscopic assessment of the dacryocystorhinostomy ostium after endoscopic surgery. Laryngoscope. 2006;116:1172-4. 